\title{
Presence of Hosta virus $X$ in New Zealand
}

\author{
J. Tang • C. Hardy • B. S. M. Lebas • L. I. Ward
}

Received: 6 June 2011 / Accepted: 19 January 2012 / Published online: 12 February 2012

(C) Australasian Plant Pathology Society Inc. 2012

\begin{abstract}
Leaf mosaic and deformation symptoms were observed on hosta plants (Hosta spp.) in a nursery in Kihikihi in the North Island of New Zealand. The virus associated with these symptoms has been identified as Hosta virus $X(\mathrm{HVX})$, using electron microscopy, mechanical transmission, ELISA and RT-PCR techniques. This is the first report of HVX in New Zealand although this virus is believed to have been present and widespread in the country for more than 10 years.
\end{abstract}

Keywords Hosta virus X·Presence $\cdot$ New Zealand

Hostas (Hosta spp.) are common garden plants in many countries including New Zealand. These species were reported to be infected with Hosta virus $X$ (HVX) for the first time in 1996 in the USA (Currier and Lockhart 1996). HVX has been subsequently reported in Korea (Ryu et al. 2002), the Netherlands (Verhoeven et al. 2006), Poland (Cajza and Zielinska 2007) and France (Jullien and Chauvel 2007) and has become a problem to hosta growers. HVX has been confirmed to be a distinct species of the genus Potexvirus in the family Flexiviridae (Park and Ryu 2003;

J. Tang $(\bowtie) \cdot$ B. S. M. Lebas $\cdot$ L. I. Ward

Plant Health and Environment Laboratory,

Investigation and Diagnostic Centres,

Ministry of Agriculture and Forestry, New Zealand,

PO Box 2095, Auckland 1140, New Zealand

e-mail: joe.tang@maf.govt.nz

\section{Hardy}

Incursion Investigation Plants and Environment, Investigation and Diagnostic Centres,

Ministry of Agriculture and Forestry, New Zealand,

PO Box 2095, Auckland 1140, New Zealand
Fajolu et al. 2009). In nature, this virus infects only hostas and is most likely to be spread by vegetative propagation or mechanical contact (Currier and Lockhart 1996), and through seed (Ryu et al. 2006).

In February 2011, a plant of Hosta sp. cv. Thomas Hogg with leaf mosaic and deformation symptoms (Fig. 1) was collected from a nursery in Kihikihi in the North Island of New Zealand. Herbaceous indicator plants, Gomphrena globosa and Nicotiana benthamiana, which had been inoculated with sap from symptomatic hosta leaves, developed necrotic local spots and systemic chlorotic lesions, respectively. No symptoms were observed on other inoculated herbaceous species (Chenopodium amaranticolor, $C$. quinoa, Cucumis sativus, N. clevelandii, N. occidentalis, N. sylvestris, N. tabacum and Phaseolus vulgaris). Electron microscopy of crude sap preparations from the hosta and symptomatic herbaceous plants revealed the presence of filamentous virus particles approximately $550 \mathrm{~nm}$ long (no virus particles were observed from other inoculated herbaceous plants which were symptomless or in healthy control plants). These viruliferous plants tested positive using HVX polyclonal antiserum in a double-antibody sandwich (DAS) enzyme-linked immunosorbent assay (ELISA) (Agdia Inc., Elkhart, USA). An RNeasy Plant Mini Kit (Qiagen, Melbourne, Australia) was used to extract total RNA from the leaves of the symptomatic hosta and herbaceous plants. The RNA was used in one-step reverse transcriptionpolymerase chain reaction (RT-PCR) tests with novel forward (5'- CCCGATGTGCTCAACCAGAT - $3^{\prime}$ ) and reverse (5'- GTGGAGGCGAAGTCGTTTCT -3') primers specific to a 464-bp fragment of the HVX coat protein gene. RTPCR reactions were performed in a total volume of $20 \mu \mathrm{L}$, containing $250 \mathrm{nmol}$ of each primer and using SuperScript $^{\mathrm{TM}}$ III One-Step RT-PCR System with Platinum ${ }^{\circledR}$ Taq DNA Polymerase (Invitrogen), as per the manufacturer's 


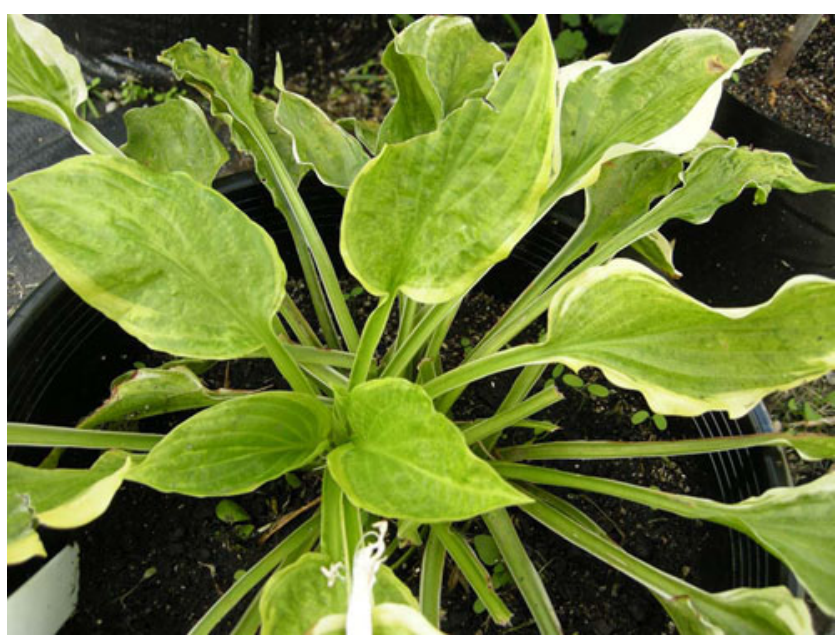

Fig. 1 Leaf mosaic and deformation symptoms on Hosta sp. cv. Thomas Hogg

instructions. Thermocycling conditions were $50^{\circ} \mathrm{C}$ for $30 \mathrm{~min}$ and $94^{\circ} \mathrm{C}$ for $5 \mathrm{~min}$ then 40 cycles of $94^{\circ} \mathrm{C}$ for $30 \mathrm{~s}, 56^{\circ} \mathrm{C}$ for $30 \mathrm{~s}$, and $72^{\circ} \mathrm{C}$ for $30 \mathrm{~s}$, followed by a final extension of $5 \mathrm{~min}$ at $72^{\circ} \mathrm{C}$. PCR products of the expected size were obtained using RNA extracted from the three symptomatic species tested. An amplicon derived from the hosta RNA was cloned using a TOPO TA Cloning Kit (Invitrogen, Carlsbad, USA) and sequenced. The consensus sequence from four clones was deposited in the GenBank (Accession number JF732917). A BLASTn search in GenBank showed 99\% nucleotide sequence identity to 47 isolates of HVX (e.g. GenBank accession FJ903405).

In order to confirm that other known hosta-infecting viruses were not the cause of the symptoms observed, the sample was screened for the presence of Arabis mosaic virus, Cucumber mosaic virus, Impatiens necrotic spot virus, Tobacco rattle virus, Tobacco ringspot virus, Tomato ringspot virus and Tomato spotted wilt virus. The hosta tested negative for all these viruses by ELISA or PCR. Therefore, it was concluded that the symptoms observed in the hosta were very probably caused by HVX alone.
A further 20 leaf samples of Hosta spp. with suspect disease symptoms were subsequently collected from the same nursery. Sixteen plants, representing 15 cultivars, tested positive for HVX using RT-PCR as described. HVX is thought to be widespread in New Zealand as the nursery investigated is the main supplier of hosta plants for garden stores throughout the country. Furthermore, HVX may have established in New Zealand for more than 10 years. In December of 2000, six hosta samples that had been collected from a park in Christchurch, in the South Island, were tested by the University of Minnesota, USA. Five out of the six samples were suggested to contain HVX particles after an examination of immunosorbent electron microscopy (B. Lockhart pers. comm., Mar 2011). This study confirms the presence of HVX for the first time in New Zealand.

Acknowledgement We thank Professor Benham Lockhart (Department of Plant Pathology, University of Minnesota, USA) for providing relevant information of HVX in New Zealand.

\section{References}

Cajza M, Zielinska L (2007) Hosta virus $X$ - a new pathogen of ornamental plants in Poland [Polish]. Progr Plant Protect 47:69-72

Currier S, Lockhart BEL (1996) Characterization of a potexvirus infecting Hosta spp. Plant Dis 80:1040-1043

Fajolu OL, Wen RH, Windham AS, Windham MT, Moulton JK, Hajimorad MR (2009) Genetic variability and phylogenetic analysis of hosta virus X. Arch Virol 154:1909-1916

Jullien J, Chauvel G (2007) 2006 Phytosanitary situation for production of flowering and foliage plants [French]. PHM Revue Horticole 491:34-39

Park MH, Ryu KH (2003) Molecular evidence supporting the classification of hosta virus $\mathrm{X}$ as a distinct species of the genus Potexvirus. Arch Virol 148:2039-2045

Ryu KH, Park MH, Lee MY, Lee JS (2006) Characterization and seed transmission of Hosta virus $\mathrm{X}$ isolated from hosta plants. Acta Horticult 722:91-93

Ryu KH, Park MH, Lee JS (2002) Occurrence of mosaic disease of hosta plants caused by hosta virus. Plant Pathol J 18:313-316

Verhoeven JThJ, Meekes ETM, Roenhorst JW (2006) Threatening viral problems for the ornamental flower sector [Dutch]. Gewasbescherming 37:188-193 